Hydraulic Engineering Repository

Ein Service der Bundesanstalt für Wasserbau

Bollaert, Erik F. R.

Numerical Modeling of Scour at Bridge Foundations on Rock

Verfügbar unter / Available at:

https://hdl.handle.net/20.500.11970/100288

Vorgeschlagene Zitierweise / Suggested citation:

Bollaert, Erik F. R. (2010): Numerical Modeling of Scour at Bridge Foundations on Rock. In: Burns, Susan E.; Bhatia, Shobha K.; Avila, Catherine M. C.; Hunt, Beatrice E. (Hg.): Proceedings 5th International Conference on Scour and Erosion (ICSE-5), November 7-10, 2010, San Francisco, USA. Reston, Va.: American Society of Civil Engineers. S. 767-776. 


\title{
Numerical Modeling of Scour at Bridge Foundations on Rock
}

\author{
E.F.R. Bollaert ${ }^{1}$, M. ASCE
}

1 President, AquaVision Engineering, Chemin des Champs-Courbes 1, CH-1024 Ecublens, Switzerland, PH +41(0)797751761, email: erik.bollaertaaquavision$\underline{\text { eng.ch }}$

\begin{abstract}
The present paper presents an application of the Comprehensive Scour Model (CSM) to quarrying and plucking of fractured rock at bridge piers. Numerical modeling of rock block plucking has been performed within the framework of the National Cooperative Highway Research Program Project NCHRP -24-29.

A two-phase transient numerical model simulates the potential movements of the block as a function of flow turbulence and stream power in the scour hole around the bridge pier. The hydraulic action on the rock blocks is automatically adapted during formation and growth of the scour hole.

Both the ultimate scour depth and the scour threshold flow velocity are determined as a function of the shape, dimensions and protrusion of the rock block, of the average upstream river bed slope and of the angle of the rock joints.

The numerical model points out the influence of turbulent eddies and block protrusion on rock block uplift.
\end{abstract}

\section{INTRODUCTION}

This paper describes a combined analytical-numerical method developed to assess the hydrodynamic uplift of rock blocks generated by turbulent flows at bridge piers founded on rock.

The method describes and computes the physics that are responsible for block ejection and provides an estimate of the ultimate depth of scour during floods at a bridge pier founded in fractured rock.

The method is based on a numerical model that has initially been developed for rock scour in plunge pools and stilling basins downstream of high-head dams (Bollaert, 2004). The equations defining turbulent pressure fluctuations at the waterrock interface have been adapted to reflect the particular flow situation in a scour hole near a bridge pier.

In the following, the hydrodynamic and geomechanic model parameters are first described in a simplified manner. Next, the numerical modeling procedure is outlined as well as the main results in terms of ultimate scour depth and critical scour velocity.

\section{HYDRODYNAMIC PARAMETERS}

\section{Upstream of the bridge pier}

The method uses a physical model based relationship for the erosive action of the flow inside the scour hole by using the stream power $\mathrm{SP}_{\mathrm{a}}\left(\left[\mathrm{W} / \mathrm{m}^{2}\right]\right)$ (Figure 1) of the 
approach flow. This parameter is derived from the base hydraulic parameters as follows:

$$
\mathrm{SP}_{\mathrm{a}}=\mathrm{V}_{\mathrm{a}} \cdot \tau_{\mathrm{a}}
$$

in which $\mathrm{V}_{\mathrm{a}}[\mathrm{m} / \mathrm{s}]$ stands for the approach flow velocity and $\tau_{\mathrm{a}}\left[\mathrm{N} / \mathrm{m}^{2}\right]$ stands for the average wall shear stress upstream. $\mathrm{SP}_{\mathrm{h}}, \mathrm{V}_{\mathrm{h}}$ and $\tau_{\mathrm{h}}$ are the corresponding stream power, velocity and shear stress in the scour hole at the pier base. In Figure 1, $\mathrm{n}$ stands for the number of rock block layers, horizontal and vertical lines represent the joint planes between the blocks and the black circles represent joint plane intersections or block corners. The terms $p_{i, k}(t)$ and $p_{i+1, k}(t)$ stand for pressure fluctuations entering the joint planes via the water-rock interface.

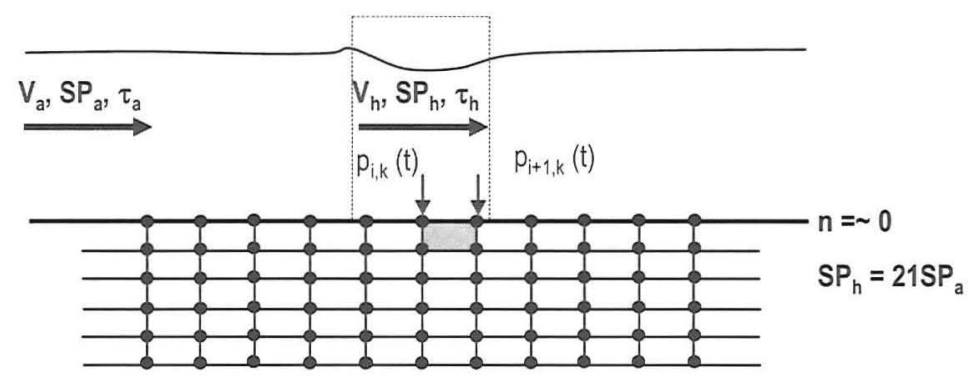

Figure 1. Hydrodynamic parameters at bridge pier founded on rock (at start of scour formation).

Beside the available stream power upstream, parameters used are written:

$\begin{array}{lll}\mathrm{SP}_{\mathrm{a} . \mathrm{adj}}=\mathrm{k}_{1} \cdot \mathrm{k}_{2} \cdot \mathrm{SP}_{\mathrm{a}} & = & \text { adjusted approach stream power } \\ \mathrm{k}_{1} & = & \text { parameter for pier shape (HEC-18) } \\ \mathrm{k}_{2} & = & \text { parameter for flow attack angle (HEC-18) }\end{array}$

The approach stream power $\mathrm{SP}_{\mathrm{a}}$ is adjusted by means of the non-dimensional parameters $k_{1}$ and $k_{2}$, which account for the pier shape and the flow attack angle respectively following HEC-18 (Richardson et al., 1993). Average flow velocity and bottom shear stress are computed based on the unitary discharge $\mathrm{q}\left[\mathrm{m}^{3} / \mathrm{s} / \mathrm{m}\right]$, the bottom slope $\mathrm{S}[\mathrm{m} / \mathrm{m}]$ and the Manning roughness coefficient $\mathrm{n}\left[\mathrm{s} / \mathrm{m}^{1 / 3}\right]$. The range of flow conditions tested is summarized at Table 1 for three types of flows:

1. Steep Slope Flood Flow (SSFF)

2. Flood Flow (FF)

3. Normal High Flow (NHF) 
Steep bottom slopes are between 1 and $10 \%$, while normal bottom slopes are between 0.05 and $1 \%$. Unitary discharges range from 2 to $50\left[\mathrm{~m}^{3} / \mathrm{s} / \mathrm{m}\right]$. Manning roughness $n_{M}$ is between 0.03 and $0.065\left[\mathrm{~s} / \mathrm{m}^{1 / 3}\right]$, depending on the tested slopes.

Table 1. Parameter values for the flow conditions approaching the bridge pier.

\begin{tabular}{|c|c|c|c|c|c|}
\hline Conditions & $\mathbf{N}^{\circ}$ & $\begin{array}{c}\mathrm{q} \\
{\left[\mathrm{m}^{2} / \mathrm{s}\right]}\end{array}$ & $\begin{array}{c}\mathrm{S} \\
{[\mathrm{m} / \mathrm{m}]}\end{array}$ & $\begin{array}{c}\mathrm{m}_{\mathrm{M}} \\
{\left[\mathrm{s} / \mathrm{m}^{1 / 3}\right]}\end{array}$ & $\begin{array}{c}\mathrm{SP}_{\mathrm{a}} \\
{\left[\mathrm{W} / \mathrm{m}^{2}\right]}\end{array}$ \\
\hline NHF & $\begin{array}{l}1 \\
2 \\
3 \\
4\end{array}$ & $\begin{array}{c}5.0 \\
5.0 \\
10.0 \\
5.0\end{array}$ & $\begin{array}{l}0.00005 \\
0.00010 \\
0.00010 \\
0.00050\end{array}$ & $\begin{array}{l}0.030 \\
0.030 \\
0.030 \\
0.030\end{array}$ & $\begin{array}{c}2 \\
5 \\
10 \\
25\end{array}$ \\
\hline FF & $\begin{array}{l}1 \\
2 \\
3 \\
4 \\
5 \\
6 \\
7 \\
8 \\
9\end{array}$ & $\begin{array}{l}10 \\
20 \\
50 \\
10 \\
20 \\
50 \\
10 \\
20 \\
50\end{array}$ & $\begin{array}{l}0.00005 \\
0.00005 \\
0.00005 \\
0.00050 \\
0.00050 \\
0.00050 \\
0.00100 \\
0.00100 \\
0.00100\end{array}$ & $\begin{array}{l}0.030 \\
0.030 \\
0.030 \\
0.030 \\
0.030 \\
0.030 \\
0.030 \\
0.030 \\
0.030\end{array}$ & $\begin{array}{c}5 \\
10 \\
25 \\
49 \\
98 \\
245 \\
98 \\
196 \\
491 \\
\end{array}$ \\
\hline SSFF & $\begin{array}{l}1 \\
2 \\
3 \\
4 \\
5 \\
6 \\
7 \\
8 \\
9\end{array}$ & $\begin{array}{c}2 \\
10 \\
15 \\
2 \\
10 \\
15 \\
2 \\
10 \\
15\end{array}$ & $\begin{array}{l}0.01 \\
0.01 \\
0.01 \\
0.05 \\
0.05 \\
0.05 \\
0.10 \\
0.10 \\
0.10\end{array}$ & $\begin{array}{l}0.065 \\
0.065 \\
0.065 \\
0.065 \\
0.065 \\
0.065 \\
0.065 \\
0.065 \\
0.065\end{array}$ & $\begin{array}{c}196 \\
981 \\
1472 \\
981 \\
4905 \\
7358 \\
1962 \\
9810 \\
14715 \\
\end{array}$ \\
\hline
\end{tabular}

\section{At the bridge pier}

As shown in Figure 1, the approach stream power $\mathrm{SP}_{\mathrm{a}}$ is transformed into its corresponding stream power $\mathrm{SP}_{\mathrm{h}}$ acting locally at the bottom of the scour hole, near the bridge pier. The relation between the local stream power and the scour hole depth and shape has been determined by physical modeling in the 1990's (FHWA research; Smith, 1994; Smith \& Annandale, 1995) and has been adapted here to match with rocky foundations:

$$
\mathrm{SP}_{\mathrm{h}} / \mathrm{SP}_{\mathrm{a}}=2.6217\left(\mathrm{n}^{*} \mathrm{~h}_{\mathrm{b}} / \mathrm{D}\right)^{(-0.6945)}
$$


in which $h_{b}[\mathrm{~m}]$ is the rock block height, $\mathrm{D}[\mathrm{m}]$ is the bridge pier diameter and $\mathrm{n}[-]$ stands for the number of horizontal layers that have been scoured. For example, at start of scour formation, the available and turbulent stream power at the bottom next to the bridge pier are considered to be about 21 times the corresponding stream power in the river upstream.

During scour hole formation, this stream power ratio reduces following the equation relating $\mathrm{SP}_{\mathrm{h}}$ to $\mathrm{SP}_{\mathrm{a}}$. For example, for $\mathrm{n}=4, \mathrm{~h}_{\mathrm{b}}=0.5 \mathrm{~m}$ and $\mathrm{D}=2 \mathrm{~m}$, Figure 2 shows that $\mathrm{SP}_{\mathrm{h}}$ is reduced to only 2.62 times $\mathrm{SP}_{\mathrm{a}}$. Hence, this progressive reduction in stream power in the scour hole allows defining the corresponding local flow velocity $V_{h}[\mathrm{~m} / \mathrm{s}]$, the local kinetic energy $E_{h}[\mathrm{~m}]$, and the local wall shear stress $\tau_{h}\left[\mathrm{~N} / \mathrm{m}^{2}\right]$.

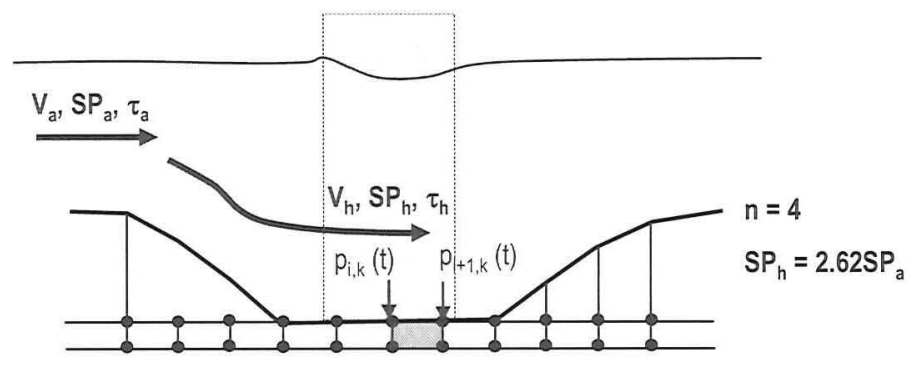

Figure 2. Hydrodynamic parameters at bridge pier founded on rock (during scour hole formation).

The local kinetic energy in the scour hole $E_{h}$ is used to define the quasi-steady pressure field around a rock block near the bridge pier. These pressures are expressed in $[\mathrm{m}]$ by multiplying $\mathrm{E}_{\mathrm{h}}$ with non-dimensional pressure coefficients $\mathrm{CP}$. The pressure coefficients depend on the protrusion of the rock block compared to its surroundings as well as on the orientation of the joints between the blocks compared to the flow direction.

Following Figure 3 and based on Reinius (1986) and USBR (2007), the following simplified range of $\mathrm{CP}$ values has been used during the computations:

$$
\begin{aligned}
& \mathrm{CP}_{6}=\mathrm{CP}_{7}=\sim 0 \\
& \mathrm{CP}_{5}=\mathrm{CP}_{8}=0.0,0.5 \text { or } 1.0 \text {, directly depending on offset of block } \\
& \mathrm{CP}_{\text {up,net }}=\text { Average }(\mathrm{CP} 6 ; \mathrm{CP} 7)-\text { Average }(\mathrm{CP} 5 ; \mathrm{CP} 8)
\end{aligned}
$$




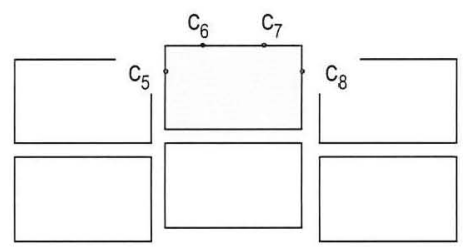

Figure 3. Location of dynamic pressure coefficients used to quantify quasisteady pressures around a rock block (based on Reinius, 1986).

Next, the bottom shear stress $\tau_{\mathrm{h}}$ is used to determine the RMS (root-meansquare) and extreme pressure fluctuations_on a rock block in the scour hole near the bridge pier. Based on Emmerling (1973), the following expressions are used:

$$
\begin{aligned}
& p^{\prime}=3 \cdot \tau_{h} \\
& p+=18 \cdot \tau_{h}
\end{aligned}
$$

By combining both quasi-steady pressures and turbulent pressure fluctuations, the total dynamic pressure signal on the rock blocks can be defined. For simplicity, a sinusoidal pressure shape has been used, defined as follows (see Figure 4):

$$
p(t)=\frac{1}{2} \cdot B \cdot \sin (\omega \cdot t)+C
$$

$\mathrm{t}=$ time duration

$\mathrm{B}=\mathrm{p}^{+}=$maximum positive deviation from quasi-steady pressure value

$\mathrm{C}=0.5 \cdot \mathrm{p}^{+}+\mathrm{C}_{5} \cdot \mathrm{E}_{\mathrm{h}}$

$\omega=2 \pi f$, with $\mathrm{f}=10 \mathrm{~Hz}$

For convenience and stability during the computations, no negative total pressures have been used. Also, the sinusoidal pressure signal has been systematically applied to both joint entrances separating the rock block from the adjacent blocks (2D approach), without any time lag between both pulses (simultaneous action). Finally, the surface pressure field acting at the surface of the block (in between both joints) has been neglected. As such, the modeled pressure situation may be considered as the most critical one that might be encountered in practice. The frequency of the pressure signal has been defined at $10 \mathrm{~Hz}$, corresponding to a frequency that may easily be reached in practice by macro-turbulent flow conditions (Toso \& Bowers 1988).

\section{GEOMECHANICAL PARAMETERS}

The main geomechanical parameters considered during the modeling are:

1. Block shape and dimensions: side length of block $\mathrm{L}_{\mathrm{b}}[\mathrm{m}]$, height of block $\mathrm{h}_{\mathrm{b}}$ $[\mathrm{m}]$, ratio $\mathrm{L}_{\mathrm{b}} / \mathrm{h}_{\mathrm{b}}$. The side length has been fixed at $1 \mathrm{~m}$, while the height has been varied (see Figure 4). 


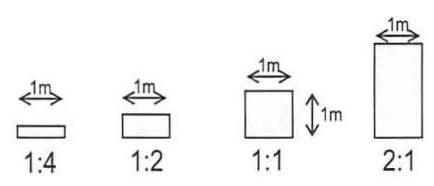

Figure 4. Modeled rock block shapes and dimensions.

2. Joint angle with the vertical: fixed at $0^{\circ}$ (vertical joints) or $60^{\circ}$ (Figure 5).

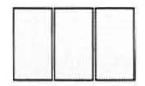

$0^{\circ}$

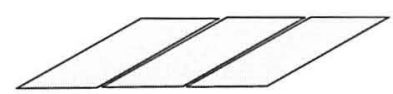

$60^{\circ}$

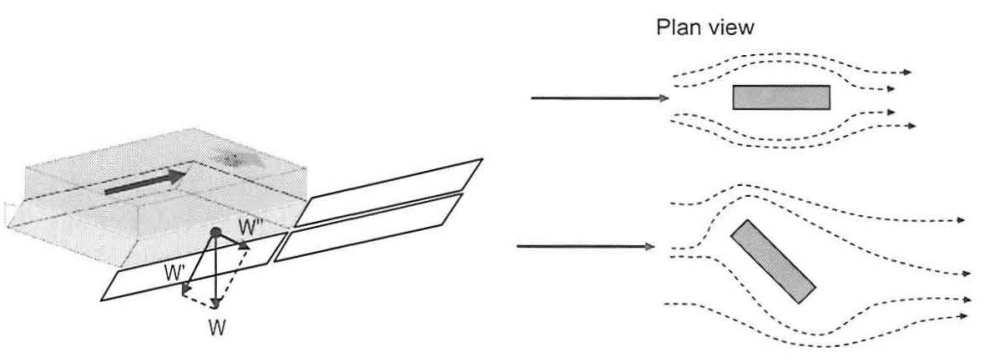

Figure 5. Modeled rock joint angles with the vertical (up) and bridge pier alignment angles with the approach flow (right).

Frictional forces inside joints have been neglected for the case of vertical joints, but have been considered for $60^{\circ}$ joints, to account for the component of gravity that is oriented perpendicularly to the joints. Friction due to the insitu stress field has been neglected. The following approach has been adopted:

- the weight of the block is subdivided into a component along the joint axis (W') and a component perpendicular to the joint axis (W'),

- W' stabilizes the block along its orientation of movement out of the surrounding mass,

- W" stabilizes the block by (perpendicular) compression of the joints between the blocks and by applying a joint friction angle $\mu$

- an additional frictional force $\mathrm{F}=\mathrm{W}$ ' $\mu$ is added to the computation of the net uplift force along the orientation of potential block movement

- the dip direction is not considered to influence the net uplift force, because the model does not account for the dip when defining flow deviation effects (pressures) generated by protrusion of blocks at the water-rock interface

3. Block density: fixed at $2650 \mathrm{~kg} / \mathrm{m}^{3}$.

4. Block protrusion: from perfectly smooth (offset $=0 \mathrm{~cm}$ ) to very rough (offset $=\min .10 \mathrm{~cm})$ 


\section{BRIDGE PIER PARAMETERS}

The bridge pier has been modeled in a simple manner by accounting for the following parameters:

1. Bridge pier diameter $D$ (or width $B$ ): fixed at $2 \mathrm{~m}$

2. Angle of bridge pier with flow angle: $0^{\circ}$ or $45^{\circ}$ (Figure 5)

The angle between the bridge pier alignment and the approach flow is accounted for by means of a $\mathrm{k}$ parameter that is applied to the stream power, following HEC-18 (Richardson et al., 1993). For example, for $0^{\circ}$ and $45^{\circ}$ angles, and a pier length to width ratio of 4 , this k parameter equals 1.0 respectively 2.3 .

\section{THE BRIDGE PIER SCOUR MODEL}

\section{Model assumptions}

A transient two-phase numerical modeling of quasi-steady and fluctuating turbulent pressures acting inside the joints of a single rock block has been performed (Bollaert, 2002, 2004). Figure 7 illustrates the basic configuration used for the numerical computations. The model applies a sinusoidal boundary pressure signal at the joint entrances and computes the pressure waves inside the joints. Only one single block is computed, considered to be located at the bottom of the scour hole in the vicinity of the bridge pier. Based on the block dimensions, the computations are performed layer per layer, with the layer height taken equal to the block height.

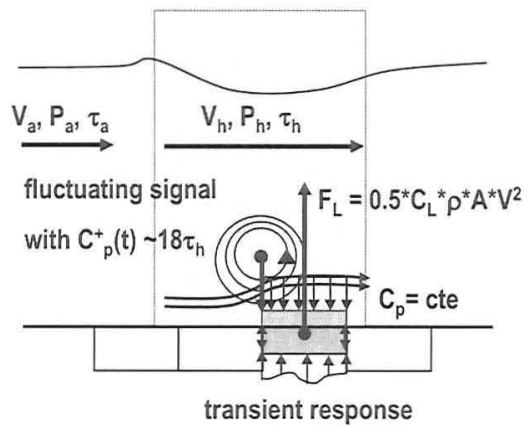

Total uplift force $=$ buoyancy + quasi-steady lift

+ turbulent lift

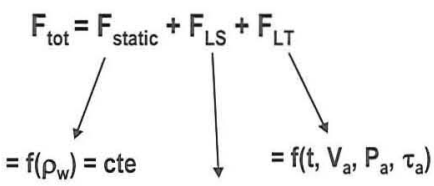

$=f\left(V_{a}\right)=c t e$

Figure 7. Uplift forces on a single rock block at a bridge pier.

Uplift or ejection of a rock block is computed by defining at each time step the total net uplift force on the block. As illustrated in Figure 7, this total uplift force is composed of three distinct components (Bollaert and Hofland, 2004):

1. static uplift = buoyancy forces

2. quasi-steady uplift $=f$ (block protrusion, local velocity in scour hole)

3. turbulent uplift $=f($ local stream power, shear stresses, pressure fluctuations) 
During time periods for which the net uplift force on the block is positive, the block will be submitted to a net uplift impulsion. This is then transformed into a net uplift velocity that is given to the mass of the block. Finally, the net uplift velocity is transformed into a net uplift height. The block is considered to be ejected when its net uplift height is larger than or equal to $20 \%$ of the total block height (Bollaert, 2004).

Once the single rock block is found to be ejected by the pressures, the whole layer is considered to be eroded and the next layer is computed until block uplift is less than $20 \%$ of block height. This corresponds to the ultimate scour depth.

\section{Output examples}

First, Figure 8 compares the here computed critical uplift velocity for a range of different rock blocks with the critical uplift velocity as defined by Reinius (1986) for CP values of 0.0 and 0.5 . It is thereby considered that, due to the small model scale and the way the pressures have been recorded, the Reinius (1986) approach does not consider the effect of turbulent eddies. When adding the effect of flow turbulence to the present computations, significantly lower critical velocities are observed. It has to be added that joint frictional effects have been neglected in the present analysis. In reality, critical uplift velocities may be significantly higher in presence of friction.

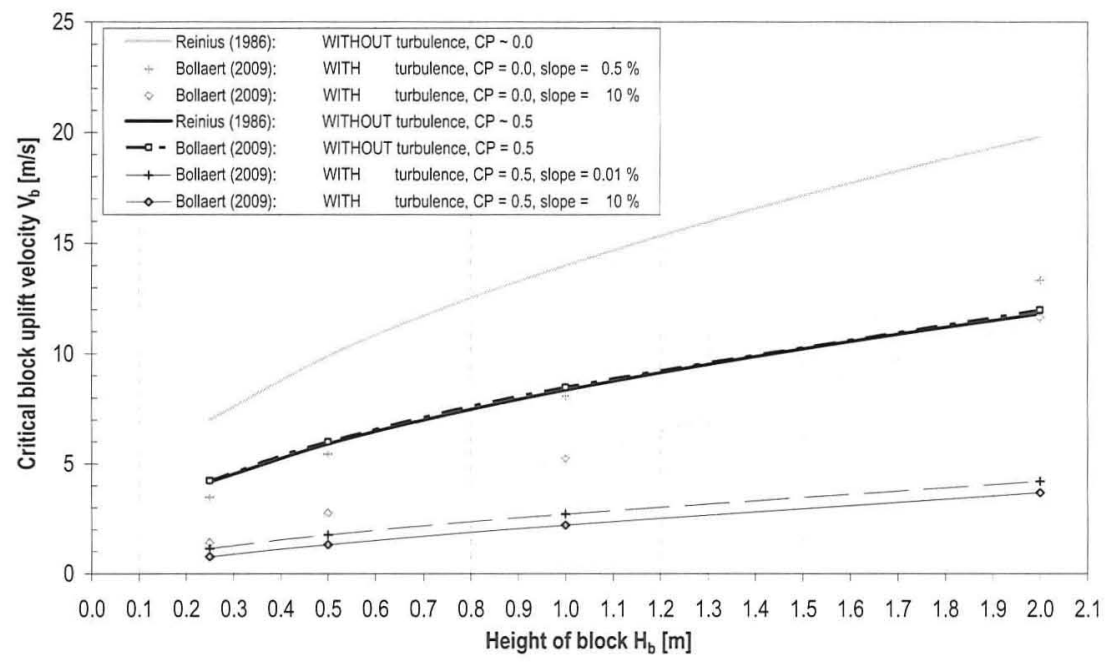

Figure 8. Comparison of critical block uplift velocities with Reinius (1986).

Second, Figure 9 illustrates the pressure signals computed over and under a $0.4 \mathrm{~m}$ high and $1.2 \mathrm{~m}$ long rock block. The block has a protrusion of $0.1 \mathrm{~m}$ and is impacted by a turbulent flow with a unitary discharge of $10 \mathrm{~m}^{2} / \mathrm{s}$ and an approach flow velocity of $5.1 \mathrm{~m} / \mathrm{s}$. The lower part of Figure 9 shows that the rock block will be uplifted by a height of about $0.22 \mathrm{~m}$, i.e. more than $50 \%$ of its total height. Hence, the block may be considered ejected from the surrounding rock mass. 

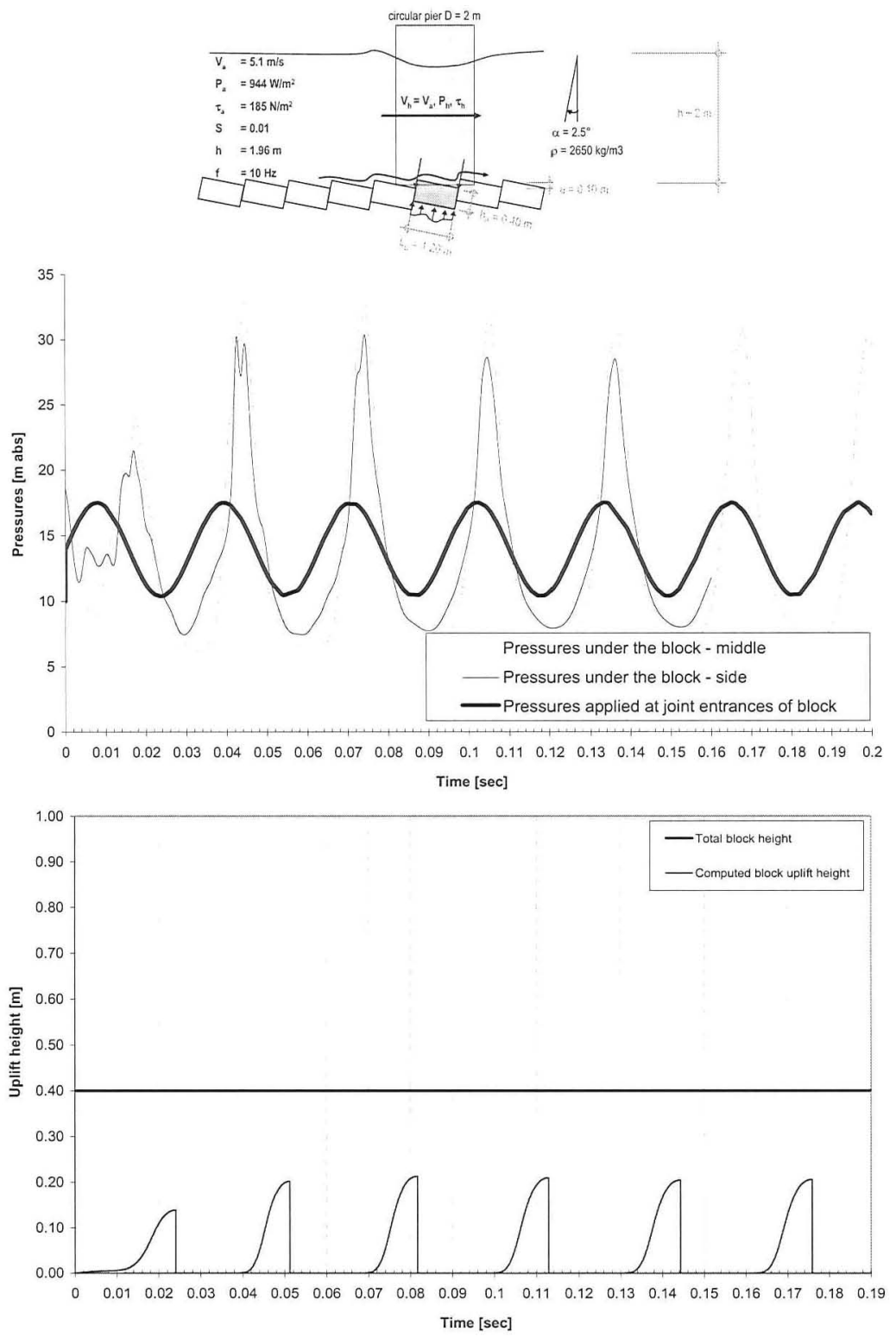

Figure 9. Pressure signals and uplift heights of a protruding rock block at a bridge pier. 


\section{CONCLUSIONS}

The present application of the Comprehensive Scour Model (CSM, Bollaert 2002) to plucking of fractured rock at bridge piers has allowed simulating the potential movements of a single rock block by direct coupling of flow turbulence and stream power inside the forming scour hole with transient pressure pulses generated underneath the blocks at the bottom of the hole.

The hydraulic action on the blocks is automatically adapted during formation and growth of the scour hole. Both the ultimate scour depth and the scour threshold velocity are determined as a function of the shape, dimensions and protrusion of the rock block, of the average upstream river bed slope and of the angle of the rock joints.

Comparison with previous research on rock block uplift points out the importance of turbulent pressure fluctuations on rock block uplift. Also, block protrusion was found to significantly enhance quasi-steady uplift forces on the blocks.

For a large range of block shapes and protrusions and for different approach flow conditions (bottom slopes, stream power), the critical block uplift velocity and the ratio of the ultimate scour depth to bridge pier diameter have been determined.

\section{ACKNOWLEDGMENT}

The present numerical modeling has been performed within the framework of the National Cooperative Highway Research Program Project NCHRP 24-29.

\section{REFERENCES}

Bollaert, E.F.R. (2002). "Transient water pressures in joints and formation of rock scour due to high-velocity jet impact." $P h D$ Thesis $N^{\circ} 2548$, Ecole Polytechnique Fédérale de Lausanne, Switzerland.

Bollaert, E.F.R. (2004). "A comprehensive model to evaluate scour formation in plunge pools.” Int. Journal of Hydropower \& Dams, 2004(1), pp. 94-101.

Bollaert, E.F.R. and Hofland, B. (2004). "The Influence of Flow Turbulence on Particle Movement due to Jet Impingement." $2^{\text {nd }}$ Scour and Erosion Conference, Nanyang, Singapore.

Smith, S.P. (1994). "Preliminary Procedure to Predict Bridge Scour in Bedrock." Report $N^{\circ}$ CDOT-R-SD-94-14, Colorado Dept of Transportation, Denver, US.

Smith, S.P. and Annandale, G.W. (1997). "Scour in Erodible Bedrock II: Erosive Power at Bridge Piers." Proceedings of North American Water and Environmental Congress, Anaheim, CA, US.

Schlichting, H. and Gersten, K. (2000). „Boundary Layer Theory.” $8^{\text {th }}$ Ed. (Revised and Enlarged), Springer-Verlag, New York.

Reinius (1986). "Rock Erosion." Water Power and Dam Construction, June 1986, pp. 43-48.

Richardson, E.V., Harrison, L.J. and Richardson, J.R. (1993). "Evaluating Scour at Bridges." FHWA-IP-90-017, US Department of Transportation, Washington, D.C.

USBR (2007). "Uplift and Crack Flow resulting from High Velocity Discharges over open Offset Joints." Report DSO-07-07, US Bureau of Reclamation, Denver.

Toso, J., Bowers, E.C. (1988). "Extreme pressures in hydraulic jump stilling basin." Journal of Hydraulic Engineering, ASCE, Vol. 114, N HY8, pp. 829-843. 